\title{
層流予混合気におけるレーザ着火過程の高時間分解光学計測*
}

\author{
中山 崇*1, 河 原伸 幸*1 \\ 富田栄二*2, 池田裕二*3
}

\section{High Temporally Resolved Optical Measurement for Laser Ignition Process of Laminar Premixed Mixtures}

\author{
Takashi NAKAYAMA, Nobuyuki KAWAHARA, \\ Eiji TOMITA*4 and Yuji IKEDA \\ ${ }^{* 4}$ Graduate School of Natural Science and Technology, Okayama University, \\ 3-1-1 Tsushima-Naka, Okayama-shi, Okayama, 700-8530 Japan
}

\begin{abstract}
This paper describes laser ignition process in a laminar premixed mixture of propane and air. The plasma was generated by focusing a second harmonic and several-nanosecond pulse emitted from a $\mathrm{Q}^{-}$switched Nd: YAG laser. Minimum ignition energy (MIE) was measured in different equivalence ratio. The growth process in the plasma and the hot kernel (flame kernel) around the MIE were observed using high-speed schlieren photography and a multi-fiber coupled to an ICCD spectrometer. The kernel size, the kernel expansion velocity and the emission spectrum history form the plasma and the kernel were determined under the ignition case and misfire case. Further, temperature of the plasma and the kernel were determined from the $\mathrm{CN}$ molecular spectra by comparing experimental and simulated (LIFBASE) spectra. The main results of this study are as follows: (1) In laser ignition method, combustion reaction begins through the cooling process in which the ion recombines to the atom, furthermore the atom recombines to the molecular after breakdown. (2) By analyzing the $\mathrm{CH}$ emission intensity history, it was considered that combustion reaction occurs confirmed about $100 \mu \mathrm{s}$ after laser pulse. (3) The temperature of the plasma and the kernel decrease with time and there were almost no difference between fire and misfire. (4) The minimum ignition energy is the smallest near the stoichiometric mixture.
\end{abstract}

Key Words: Premixed Flame, Laser-ignition, Ignition, Extinction, Laser-induced Plasma, Plasma Emission, Chemical Reaction, Spectroscopic Measurement

\section{1. 緒言}

気体に $10^{10} \mathrm{~W} / \mathrm{cm}^{2}$ 以上のレーザ光が照射されると， その気体が絶縁破壊（ブレイクダウン）し，局所的に 高温高圧のプラズマが生成される(1).このブレイクダ ウンプラズマは，気体の組成や濃度を計測するレーザ

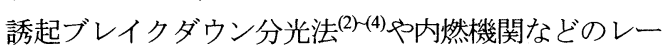
ザ着火法として利用されている(5)-(9)。レーザ着火は, 着火位置や着火タイミング, 着火エネルギの制御が可 能であり，非挿入であるため電極などによる熱損失が 無い, また, 光学系の選択により多点での着火が可能 であるなど，従来の電気的着火システムでは見られな い利点があり, 最近広く研究が行われている(10)(11).ま

\footnotetext{
* 原稿受付 2007 年 11 月 16 日.

*1 正員, 岡山大学大学院自然科学研究科(业700-8530 岡山市 津島中 3-1-1).

*2 正員, フェロー, 岡山大学自然科学研究科.

*3 正員, イマジニアリング(株) (焉 657-0038 神戸市灘区深田 町 4-1-1 ウエルブ六甲道 2 番街 351).

E-mail : tomita@mech.okayama-u.ac.jp
}

た，ブレイクダウン䦨値や最小着火エネルギ，燃焼速 度など, レーザ着火の機構についても研究が進められ ている(12)(17).

著者らはこのレーザ着火法に着目し，バーナから噴 出された可燃性予混合気をレーザ誘起プラズマにより 着火させ, その着火過程を解明してきた. レーザ着火 過程をシュリーレン法で撮影した結果を図 1 に示寸. 時間経過とともにプラズマ, 衝撃波, カーネル（火炎 核), 安定火炎が順番に形成されることが観察された. これらの現象における各過程の時間スケールは, ns オ 一ダから $\mu \mathrm{s}$ オーダのプラズマ生成過程, $\mu \mathrm{s}$ オーダで伝 播していく衝撃波膨張過程, $\mu \mathrm{s}$ から $\mathrm{ms}$ オーダで形成 されるカーネル (火炎核) 形成過程, ms オーダでの火 炎形成過程であり，全体として非常に幅広い時間スケ 一ルを有する現象であることがわかる．また，時間経 過とともに観測対象であるプラズマやカーネルの形状 が変化していくため, レーザ着火法における着火機構 


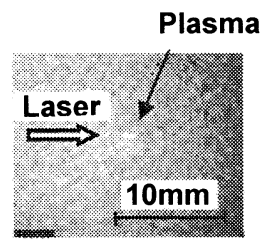

$t=1 \mu s$

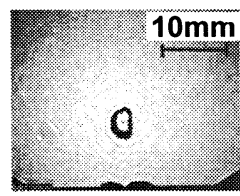

$\mathbf{t}=30 \mu \mathrm{s}$

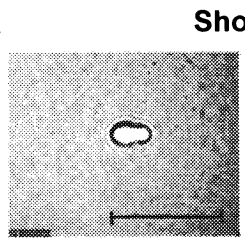

$t=3 \mu s$

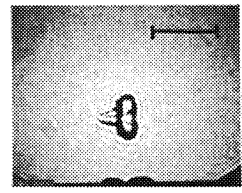

$t=120 \mu s$

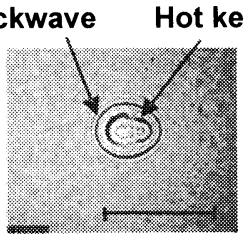

$t=5 \mu s$

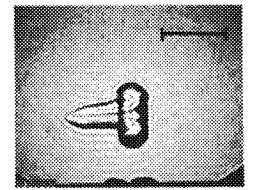

$t=340 \mu s$

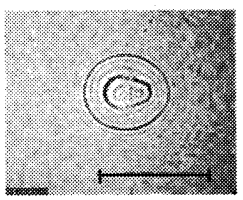

$\mathbf{t}=7 \mu \mathrm{s}$

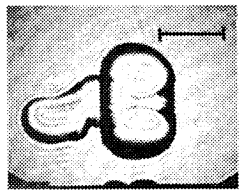

$t=1360 \mu s$

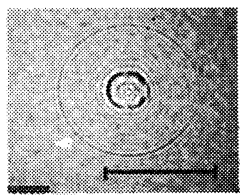

$t=11 \mu \mathrm{s}$

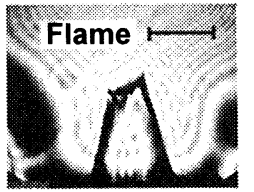

$\mathrm{t}=49.8 \mathrm{~ms}$

Fig.1 Schlieren images of laser ignition $(\phi=1.0, \mathrm{f}=200 \mathrm{~mm})$

を明確にするためには高時間・高空間分解能を備えた 測定手法が必要である。しかし，これまでにレーザ着 火における着火現象を時間経過とともに観察し，その 着火機構を詳細に調べた例はない．

著者らは，これまでにレーザブレイクダウンプラズ マの諸特性を調査するために, 大気圧下の空気中にレ ーザブレイクダウンプラズマを生成し，フレーミング カメラと長距離顕微鏡を組み合わせた高速度拡大撮影 を用い，プラズマ生成過程におけるプラズマ形状の時 系列変化とレーザ入射エネルギが及ぼす影響について 調べた(18)(19). また, カセグレン光学系とバンドルファ イバを用いた多点局所自発光計測システム ${ }^{(19)}$ 用い て，レーザ誘起プラズマ自発光スペクトルの時間・空 間分布を計測し，酸素原子の発光スペクトルよりレー ザ軸方向に沿った温度分布などの解析を行った。これ らの結果から, 空気中におけるレーザ誘起プラズマは, 生成から膨張, 消滅という過程を経て, 時間経過と共 にプラズマが冷却されていく様子が確認できた. また, レーザ入射エネルギがプラズマの膨張に与える影響は 大きいが，プラズマ温度への影響は小さいことが分か った.

これらの結果を踏まえ, 本報ではレーザ誘起プラズ マを可燃性ガス中に生成し，このプラズマによって混 合気を着火させるという機構を明確にすることを目的 とする. まず, 最小着火エネルギの調査を行い, 次に, 計測された最小着火エネルギ付近でのプラズマ生成過 程，カーネル生成過程のシュリーレン撮影，自発光ス ペクトルの分光計測を行い, 着火, 消炎に至る場合の 相違を調查した結果について報告する.

\section{2. 実験装置および実験方法}

本研究では，図2 (a) (b)に示寸シュリーレン撮影と分 光計測の $2 つ の$ 計測手法を用いて実験を行った. 本実 験で用いた光源は, Qスイッチ Nd:YAG レーザ(Spectra Physics 社製：LAB150）の第 2 高調波（波長 $532 \mathrm{~nm}$, パルス幅 10ns）である.ここで，レーザパルス幅は， レーザ照射開始から照射完了までの時間で定義してい る. また，レーザビームは反射防止膜付レンズ（焦点 距離 $\mathrm{f}=100,200 \mathrm{~mm}$ ）によって集光し, 予混合円管バ 一ナ出口（内径 $10 \mathrm{~mm}$ ）中心軸上の位置にブレイクダ

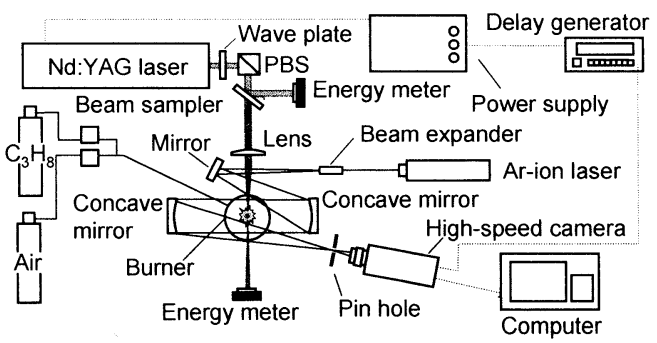

(a) High-speed schlieren photography

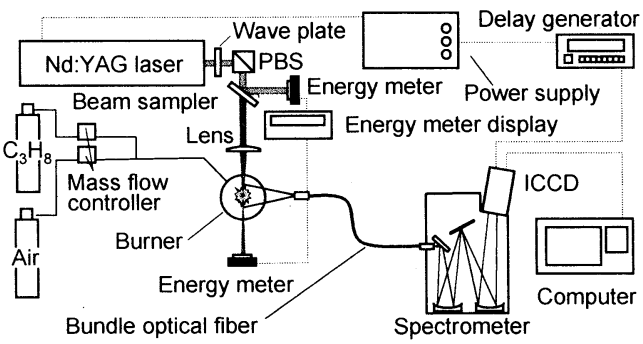

(b) Spectroscopic measurement

Fig.2 Experimental set-up 
ウンさせ，プラズマを生成させた，燃料にはプロパン を用い, 乾燥空気との混合気流量を $5 \mathrm{~L} / \mathrm{min}$ 一定 (混合 気流速 $1.06 \mathrm{~m} / \mathrm{s}$ ) とし，当量比枚任意に変化させた. このとき,各ガスの流量はマスフローコントローラ(コ フロック社製 : model 3200）で制御した. レーザの入 射エネルギは，フラッシュランプのエネルギの増減に よるパルス光の時空間的なプロファイルの変化 ${ }^{(20)}$ 防ぐためにフラッシュランプエネルギを一定とし, $1 / 2$ 波長板と偏光ビームスプリッタを用いることにより調 節した. 入射エネルギ $\mathrm{E}_{\mathrm{i}}$, 透過エネルギ $\mathrm{E}_{\mathrm{t}}$ は, 二つの 焦電型エネルギメータ（Ophir：PE-25）を用いて集光 位置前後にて計測し，スパークエネルギ $\mathrm{E}_{\mathrm{s}}\left(=\mathrm{E}_{\mathrm{i}}-\mathrm{E}_{\mathrm{t}}\right)$ と定義した.

ブレイクダウン後における火炎核形成過程を観察 するために超高速度ビデオカメラ（島津製作所製：

Hyper Vision HEX-108, 撮影領域: $30 \times 25 \mathrm{~mm}^{2}$, 分解 能: $0.1 \mathrm{~mm} / \mathrm{pixel}$ )を用いてシュリーレン撮影を行った. また, 着火過程において時系列分光計測を行うために, 多点ファイバ (コア径: $150 \mu \mathrm{m}$, ファイバ本数 : 12 本) を介した ICCD 付き分光器 (grating : 300 lines $/ \mathrm{mm}$ ) を 用いた. なお，プラズマ自発光強度に比べて燃焼反応 によるラジカル自発光強度は非常に小さいため, ラジ カル自発光も検出できるように, ファイバの集光測定 体積は NA（開口数 $\sin \theta, \theta$ : ファイバ受光角の $1 / 2$ ) の広がりを持った領域とし, 火炎核全体からの光を計 測するようにした. また, 超高速度ビデオカメラや ICCD 分光器などの各計測機器における計測タイミン グおよび計測時間は, ディレイジェネレータ（Stanford Research Systems 社製：DG535）を用いて制御した.

\section{3. 最小着火エネルギ}

本研究では，レーザ着火機構を調べるために，まず 最小着火エネルギの計測を行った. 図3に (a)着火時, (b)失火時のカーネル形状の時間的変化をシュリーレ ン法によって撮影した結果を示寸. 図 3 の(a) (b)におい て, фおよび $\mathrm{E}_{\mathrm{i}}$ は等しく $\left(\phi=1.0, \mathrm{E}_{\mathrm{i}}=5.9 \mathrm{~mJ}\right), \mathrm{E}_{\mathrm{s}}$ が $(\mathrm{a}) \mathrm{E}_{\mathrm{s}}$ $=1.2 \mathrm{~mJ}$, (b) $\mathrm{E}_{\mathrm{s}}=1.0 \mathrm{~mJ}$ と異なる. ここで, プラズマ消 滅後に膨張していく楕円体部は, プラズマの冷却過程 で形成される高温ガス部であるか, あるいは化学反応 による発熱反応を伴う火炎核であるか，シュリーレン 画像からでは判断できない. しかし, この楕円体部が いずれであるかは，着火機構を明確にする本研究の目 的として非常に重要である. したがって, 本研究では 楕円体部をカーネルと呼び，広義に扱うものとする。 図3 (a)の着火時にはブレイクダウン後に生成されたカ 一ネルが楕円状に膨張する様子が確認できる。一方,
図 3 (b)の失火時では, ブレイクダウン後に生成された カーネルが約 $800 \mu \mathrm{s}$ 後に消滅する様子が確認できる. 前章で述べたように， $\mathrm{E}_{\mathrm{s}}$ はブレイクダウン時において 吸収されたエネルギ量と定義したので， $E_{s}$ はブレイク ダウンに伴うプラズマ生成に用いられたエネルギと考 えられる.つまり, 混合気が着火する場合では, $\mathrm{E}_{\mathrm{s}}$ は 着火エネルギとして扱うことができる．ただし， $\mathrm{E}_{\mathrm{s}}$ はあくまで見かけのエネルギである。 $\mathrm{Ma} 5^{(7) や ~}$ Phuoc $^{(17)}$ が述べているように, ブレイクダウン時に減 衰するエネルギ量は，プラズマに吸収される量だけで はなく, 膨張するプラズマによるレーザ光の散乱や回 折に伴う減衰量がある. したがって, 正確な着火エネ ルギを計測するためには，それらの減衰量を考慮する

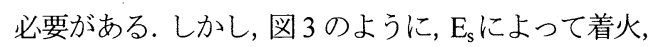
失火の現象が異なってくるため, $\mathrm{E}_{\mathrm{s}}$ は着火・失火に影 響を与えるエネルギ量であり, 着火・失火を評価でき る. そこで, 図 3(a)のようにカーネルが時間経過に伴 つて膨張していく場合を火炎伝播に十分なエネルギを 持った火炎核が形成されたと考え，このような場合を 着火として定義し， $\mathrm{E}_{\mathrm{s}}$ を着火エネルギとして用いた. また, 最小着火エネルギに関しては, 任意の当量比に おいて $100 \%$ の確率で着火する場合における $\mathrm{E}_{\mathrm{s}}$ の值を 最小着火エネルギと定義 した. 図 4 より, 最小着火エ ネルギは当量比が量論混合比に近づくにつれ小さくな

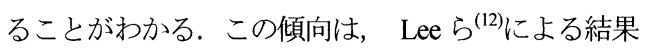

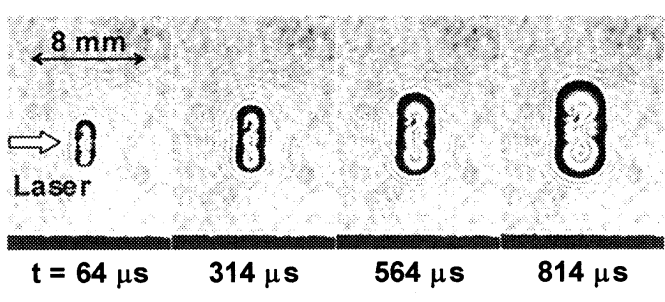

(a) Fire $\left(E_{\mathrm{i}}=5.9 \mathrm{~mJ}, \mathrm{E}_{\mathrm{s}}=1.2 \mathrm{~mJ}\right)$

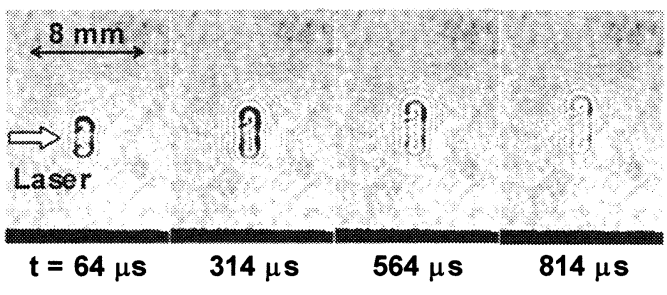

(b) Misfire $\left(\mathrm{E}_{\mathrm{i}}=5.9 \mathrm{~mJ}, \mathrm{E}_{\mathrm{s}}=1.0 \mathrm{~mJ}\right)$

Fig. 3 Spark kernel development process $(\phi=1.0, \mathrm{f}$ $=100 \mathrm{~mm}$ ) 


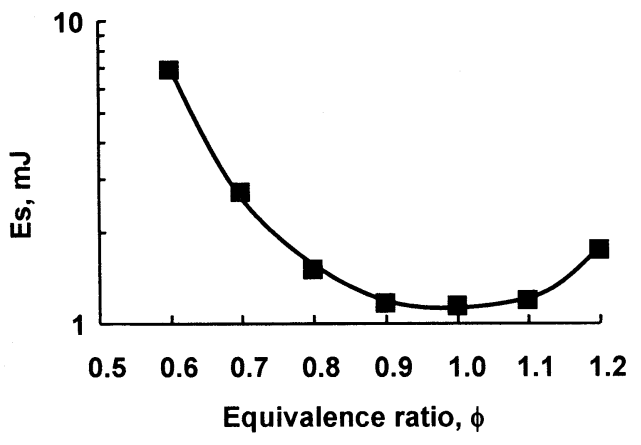

Fig. 4 Minimum ignition energy for $\mathrm{C}_{3} \mathrm{H}_{8}$ /air flow

とよく一致している. また, $\phi=0.5$ 以下の希薄領域で は，プロパンの希薄可燃限界以下であるために入射エ ネルギを増加させても火炎核が発達せず，着火には至 らなかった。これらの值は, Lewis ら ${ }^{(21)}$ が電気火花を 用いて最小着火エネルギを調査した結果と比べて一桁 ほど大きい，この理由は，先に述べたようにレーザエ ネルギの散乱などによる減衰分が $\mathrm{E}_{\mathrm{s}}$ に含まれている からであると考えられる. また, Beduneau ら $^{(13)}$ が調査 しているように，最小着火エネルギは混合気の流速や 集光レンズの焦点距離によって変化するため, それら の影響についても検討する必要がある.

\section{4. カーネル成長過程}

図 3 に示した画像からカーネルの投影面積を求め, その等価半径を算出し, カーネルの大きさが着火, 失 火の各現象において時間的に変化していく様子を解析 した。 その結果を図 5 に示寸。なお，図の各プロット 点は,それぞれの時間において 20 枚の画像を用いて求 めた平均值を示してある。ここで， $\mathrm{t}$ をレーザ照射開 始時期からの遅れ時間とする. 失火の場合では, カ一 ネルの消滅のため $\mathrm{t} \fallingdotseq 800 \mu \mathrm{s}$ までしか解析できなかった. $\mathrm{t}=64 \mu \mathrm{s}$ における着火，失火時のカーネル半径はほぼ同 じであるが， $\mathrm{t}=100 \mu \mathrm{s}$ 付近から両者の差は時間経過に 伴って大きくなっていく. 次に, 図6にカーネル半径 の時系列変化から, 着火, 失火の各過程におけるカー ネルの膨張速度を解析した結果を示寸. 失火時では膨 張速度が急速に減少していくのに対し, 着火時では, $\mathrm{t}$ $\fallingdotseq 200 \mu \mathrm{s}$ までは失火時と同椂に膨張速度は減少傾向を 示寸が，それ以降ではゆるやかに膨張速度が増加して いく結果が得られた.このように，失火時と着火時に おいて $\mathrm{t}=200 \mu \mathrm{s}$ までに見られるカーネル膨張速度の減 少は, プラズマ消㓕後の高温ガス部が断熱膨張するた めであると考えられる. また, 着火時における $\mathrm{t}=200 \mu \mathrm{s}$

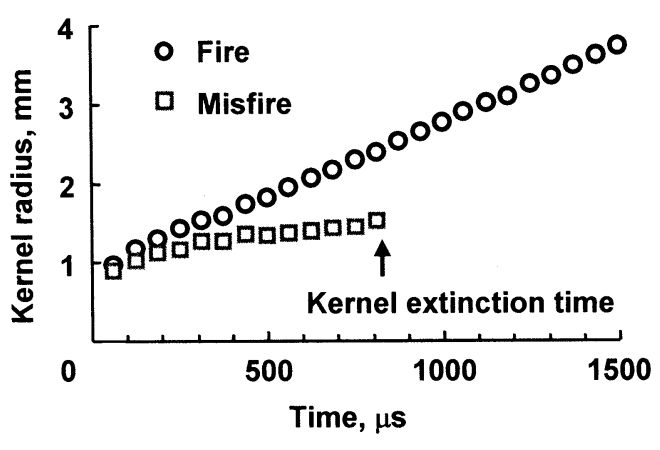

Fig. 5 Growth of spark kernel

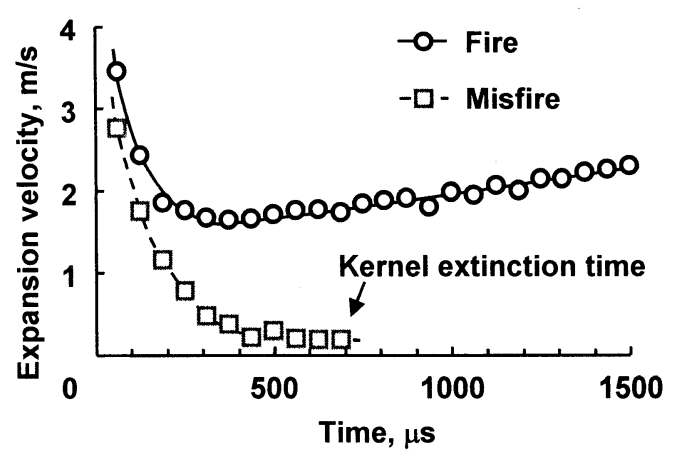

Fig. 6 Kernel expansion velocity

以降での膨張速度の増加は，断熱膨張に伴う温度減少 過程から燃焼反応過程に遷移した様子を示していると 考えられる. そこで, 次章では本章で述べた着火時, 失火時のカーネル形成過程における分光計測を行い, その発光履歷から着火過程について検討する.

\section{5. 着火過程における時系列自発光スペクトル}

図 7 に, レーザ照射による着火時, 失火時の自発光 スペクトルの時系列変化を示す. 各図の右上にはレー ザ照射からの時間を示しており,それぞれ 70 データを 平均した. まず, $\mathrm{t}=0.01 \mu \mathrm{s}$ 後においては, 制動放射や 電子の再結合放射と思われる連続スペクトル (22)が確 認でき, 窒素や酸素の一価や二価の電離状態であるイ オン発光が見られる. すなわち, ブレイクダウン直後 はプラズマ内において原子の電離が促進されており, 高温状態であることが推測できる. 次に, $\mathrm{t}=0.1 \mu \mathrm{s}$ では, 連続スペクトルが大幅に減少し, 水素の原子発光や, $\mathrm{CN}$ \%の分子発光が確認され始める. そして, $\mathrm{t}=1 \mu \mathrm{s}$ 後に は, 連続スペクトル, 水素原子発光ともに検出されず, $\mathrm{CN}^{*}$ の発光と微弱な $\mathrm{OH}^{*}$ の発光がからうじて確認で 
きる. $t=10 \mu \mathrm{s}$ では, $\mathrm{CN}^{*}$ の発光は减少し, 燃焼反応時 に見られる $\mathrm{OH}^{*}, \mathrm{CH}^{*}, \mathrm{C}_{2}{ }^{*}$ のラジカル自発光が確認 できる. そして, 失火時においては発光強度が減少し ていき， $\mathrm{t}=1000 \mu \mathrm{s}$ には発光がほとんど検出できなくな った. 一方, $\mathrm{t}=100 \mu \mathrm{s}$ 以降では着火時には減少傾向で あった発光強度が増加していく。このように発光強度 が減少しながらイオンから原子, 原子から分子へと遷 移するのは, ブレイクダウンによってばらばらになっ た電子，イオン，原子がプラズマおよびカーネルの温 度が低下することによって再結合していく過程を示し ていると考えられる. 未燃混合気には含まれない $\mathrm{CN}^{*}$ 分子の発光が確認されたことは, プラズマの冷却過程 において $\mathrm{C}$ 原子と $\mathrm{N}$ 原子が $\mathrm{CN}^{*}$ 分子として結合し, 生成されたと考えられる.

次に，着火時，失火時においてプラズマおよびカー ネルのもつ温度履歴がどのように変化しているかを図
7 で示した発光スペクトルを用いて調査した. 分子の 自発光スペクトルの形状は, 回転, 振動といったエネ ルギ状態によって決まり, スペクトルの線幅や隣接し たスペクトルの強度比から回転温度, 振動温度を見積 もることができる ${ }^{(23) \sim(25)}$. また，本実験条件であるよ うな大気圧下においては, 衝突緩和によってプラズマ 冷却過程の最終段階である分子発光状態では局所熱平 衡 (Local Thermal Equilibrium, LTE) 状態に近いと仮定 すると, 分子スペクトルから求められた振動回転温度 はガス温度を示すと考えられる，そこで，分子発光ス ペクトルより温度を解析するために, 十分な発光強度 が計測できた $\mathrm{CN} *$ の発光スペクトルを用い, シミュレ ーションプログラムである LIFBASE ${ }^{(26)}$ で計算したス ペクトル形状と比較して温度を算出した. LIFBASE で 得られた $\mathrm{CN}^{*} \mathrm{~B}-\mathrm{X}$ 帯の発光スペクトルと温度との関 係を図 8 に示す.このとき, 与えた温度は熱平衡を仮

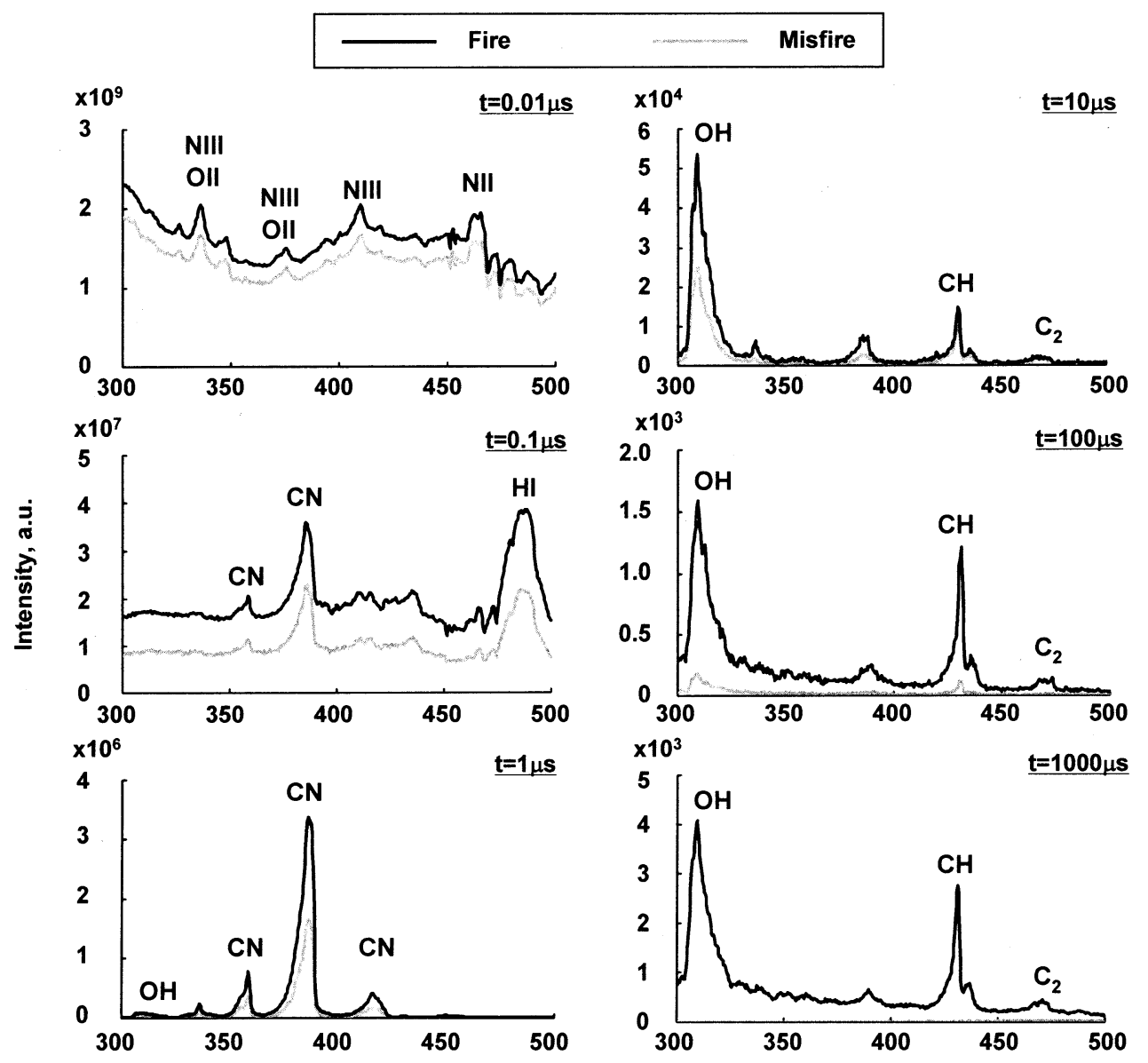

Fig. 7 Temporal variation of emission spectrum 
定し，発光強度は， $\mathrm{CN}^{*} \mathrm{~B}-\mathrm{X}(0,0)$ 帯のピーク值により 正規化してある. 図 8 より, 温度の増加に伴い発光ス ペクトルの形状および, CN* B-X $(1,0)$ 帯, CN* B-X $(0,1)$ 帯のそれぞれのピーク值が変化していることが確認で きる. そこで, LIFBASE で計算した CN* B-X $(1,0)$ 帯 と $\mathrm{CN}^{*} \mathrm{~B}-\mathrm{X}(0,0)$ 帯のピーク值の強度比を算出し, その 強度比と与えた温度との関係を図 9 に示寸. 温度増加 に伴い発光強度比は単調に増加していくことがわかる。 これより，実験によって得られた $\mathrm{CN} *$ スペクトル形状 から CN* B-X $(1,0)$ 帯と CN* B-X $(0,0)$ 帯のピーク値の 強度比を算出し，その值を図 9 で得られた近似曲線に 代入することで平衡温度 $\mathrm{T}$ を求めた. 図 10 に, 実験 で得られたスペクトルと LIFBASE で計算したスペク トルを示す． $\mathrm{T}=6120 \mathrm{~K}$ と仮定すると，両者のスペクト ル形状がよく一致した. 次に，この方法を用いて $\mathrm{CN}^{*}$ の発光スペクトルより温度履歷の解析を行った結果を 図 11 に示す．なお，各プロット点は 50 データの平均 值を，また誤差棒は標淮偏差を示している. CN*より

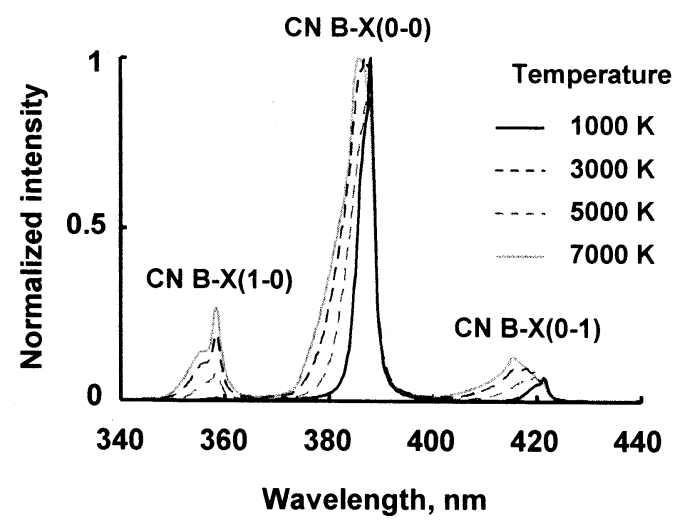

Fig. 8 LIFBASE simulations of $\mathrm{CN}$ B-X emission spectrum as a function of temperature in LTE

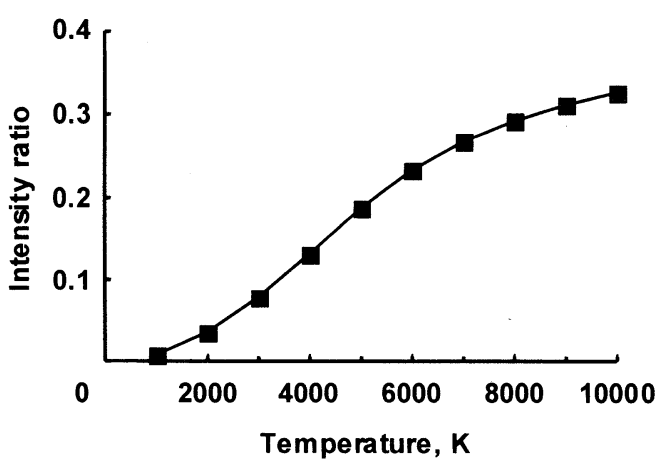

Fig. 9 Intensity ratio between CN B-X $(0,0)$ and CN B-X $(1,0)$ as a function of temperature
求めた温度は，着火と失火の両者の場合において同様 な傾向を示し, $\mathrm{t}=0.3 \mu \mathrm{s}$ における $9000 \mathrm{~K}$ 付近から, $\mathrm{t}=3 \mu \mathrm{s}$ における 5000K まで急速に減少している. $\mathrm{t}=3 \mu \mathrm{s}$ 以降 は, 十分な $\mathrm{CN} *$ 発光強度が得られていないため, 温 度を求めることができなかった。これより，図 11 に示 寸温度の減少は，プラズマおよびカーネルが周囲ガス によって冷却されるためであると考えられる.

次に, い燃焼反応が開始するかを発光履歴をもと に調査した．そこで，燃焼反応に起因して生成される $\mathrm{CH}^{*}$ ラジカルに注目した. $\mathrm{CH}^{*}$ ラジカルの発光強度の 時間変化を図 12 に示寸. 着火, 失火の場合で発光強度 に少し差はあるものの， $\mathrm{t} \fallingdotseq 2 \mu \mathrm{s}$ から $\mathrm{CH}^{*}$ の発光が確 認でき，さらに $\mathrm{t} \fallingdotseq 50 \mu \mathrm{s}$ までは同様な隇少傾向を示寸 ことがわかる．しかし，その後強度が単調に減少する 失火の場合と比べて, 着火の場合には強度の減少が緩 やかになり, $t=200 \mu \mathrm{s}$ 以降では発光強度が増加してい る.ここで，着火，失火時に見られる発光強度の減少 は，プラズマおよびカーネルの泠却によるものと考え

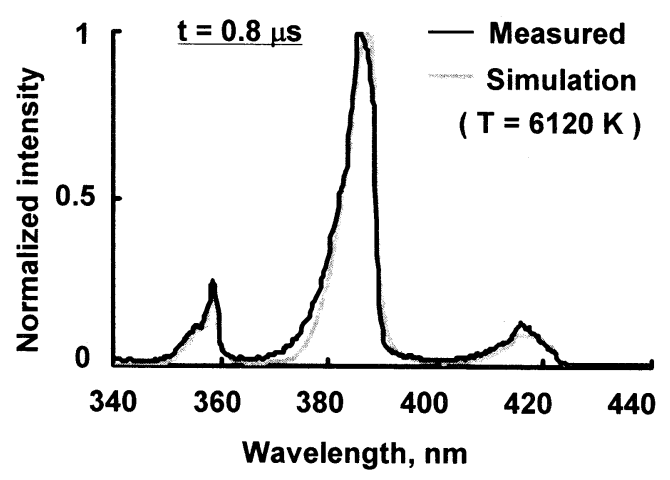

Fig. 10 Comparison of experimental and calculated $\mathrm{CN}$ spectra

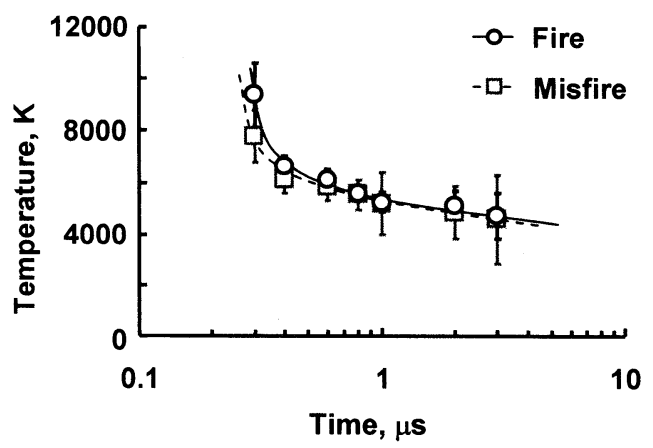

Fig. 11 Temporal variation of kernel temperature 


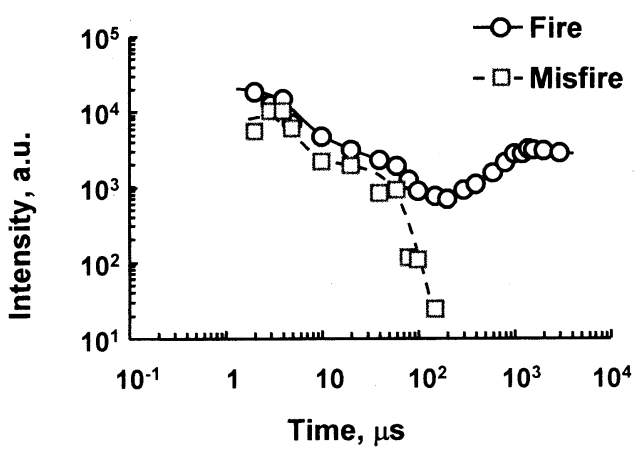

Fig. 12 Temporal variation of $\mathrm{CH}$ emission intensity

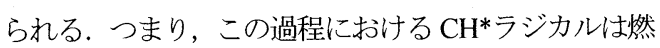
焼反応による生成より, $\mathrm{CN}^{*}$ 分子と同様に冷却過程に おけるC原子と H原子の再結合による生成が大きく影 響していると考えられる. 一方，然焼反応を考えた場 合, 火炎核における $\mathrm{OH}^{*}, \mathrm{CH}^{*}, \mathrm{C}_{2}{ }^{*}$ の各ラジカルな どは連鎖分岐反忘によって指数関数的に増加していく ものであり，その結果着火に至ると考えられる．した がって, 着火時において $\mathrm{CH}^{*}$ ラジカルの発光強度が減 少から増加に転じたことは, カーネルの泠却における 発光強度の減少から, 燃焼反忘による $\mathrm{CH}^{*}$ ラジカルの 生成に伴う発光強度の増加に遷移したことを意味して いると考えられる.以上のことから，レーザ着火では， ブレイクダウン後 $\mathrm{t} \fallingdotseq 100 \mu \mathrm{s}$ 付近で然焼が開始している と考えられ, $\mathrm{CH}^{*}$ ラジカルの発光強度が増加していく

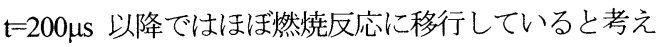
られる.これらの時間スケールは，4 章で述べたカー ネルの断熱膨張から火炎伝播を伴う膨張に変化する時 間スケールと一致していることがわかる．また，一般 的に層流予混合火炎における化学反応特性時間が数百 $\mu \mathrm{s}$ から数 ms と言われている ${ }^{(27)(28)}$ が，同等なスケール である。

最後に, $t=50 \sim 100 \mu \mathrm{s}$ 付近は, 燃焼反応開始時期で あり，レーザ着火における着火機構を明確にするため には非常に重要な過程である. そこで，今回解析でき なかったこの時間スケールにおけるカーネルの温度履 歴や大きさなどを今後詳細に調査していく予定である.

\section{6. 結 言}

レーザ着火法における着火過程を高速シュリーレン 撮影, 拡大直接撮影, 時系列分光計測を用いて調査し, その着火機構を時系列的に調査した. 主な結果は以下 の通りである.
（1）着火過程の高速シュリーレン撮影および時系列 分光計測より, レーザ着火における着火過程は, ブレ イクダウン後のイオン, 原子, 分子発光と遷移してい く泠却過程を経て, 燃焼反応が開始し, 着火に至る.

（2） $\mathrm{CH}^{*}$ の発光履歴から，レーザ照射後約 $100 \mu \mathrm{s} に$ おいて燃焼反応が開始される様子が確認できた。

(3) $\mathrm{CN}^{*}$ の発光スペクトルから温度履歴を算出した. プラズマおよびカーネルの冷却過程においては着火, 失火における温度履歴の違いはなかった。

（4）着火過程の高速シュリーレン撮影結果より, 最 小着火エネルギを計測し, 量論混合比付近において最 小となった.

\section{謝辞}

本研究の一部は, 平成 18 年度科研費基盤研究(B) 183 60102 により行われた.ここに記して謝意を表す。

\section{文献}

(1) Rosen, D. I., Weyl, G., Laser-induced breakdown in nitrogen and the rare gases at 0.53 and $0.357 \mu \mathrm{m}$, Journal of Physics D: Applied Physics, Vol.20 (1987), pp.1264-1276.

(2) Stavropoulos, P., Michalakou, A., Skevis, G., Couris S., Quantitative local equivalence ratio determination in laminar premixed methane-air flames by laser induced breakdown spectroscopy (LIBS), Chemical Physics Letters, Vol.404 (2005), pp.309-314.

(3) Ferioli, F., Buckley, S.G., Measurements of hydrocarbons using laser-induced breakdown spectroscopy, Combustion and Flame, Vol.144 (2006), pp.435-447.

(4) Ikeda, Y., Nishiyama, A., Kawahara, N., Tomita, E., Nakayama, T., Local equivalence ratio measurement of $\mathrm{CH}_{4} /$ air and $\mathrm{C}_{3} \mathrm{H}_{8} /$ air laminar flames by laser-induced breakdown spectroscopy, ALAA Paper, No.2006-0965, (2006).

(5) Piock, W. F. Winklhofer, E., Matsumoto, Y., The AVL Ignition Laser and Practical Applications, Preprints of Meeting on Automotive Engineers, No.1-05, 20055007.

(6) Weinrotter. M., Kopecek, H., Tesch, M., Wintner, E., Lackner, M., Winter, F., Laser ignition of ultra-lean methane/hydrogen/air mixtures at high temperature and pressure, Experimental Thermal and Fluid Science, Vol. 29 (2005), pp.569-577.

(7) Ma, J.X., Alexander, D.R., Poulain, D.E., Laser Spark Ignition and Combustion Characteristics of Methane-Air Mixtures, Combustion and Flame, Vol.112 (1998), pp.492-506.

(8) Weinrotter, M., Kopecek, H., Wintner, E., Lackner, M., Winter, F., Application of laser ignition to hydrogen-air mixtures at high pressures, International Journal of Hydrogen Energy, Vol.30 (2005), pp.319-326.

(9) Hill, R. A., Ignition-delay times in laser initiated combustion, Applied Optics, Vol.20, No.13(1981), pp.2239-2242.

(10) Morsy, M. H., Ko, Y. S., Chung, S. H., Laser-Induced Ignition Using a Conical Cavity in $\mathrm{CH}_{4}$-Air Mixtures, Combustion and Flame, Vol.119 (1999), pp.473-482.

(11) Phuoc, T. X., Single-Point Versus Multi-Point Laser Ignition: Experimental Measurements of 
Combustion Times and Pressures, Combustion and Flame, Vol. 122 (2000), pp. 508-510.

(12) Lee, T. W., Jain, V., Kozola, S., Measurements of Minimum Ignition energy By Using Laser Sparks for Hydrocarbon Fuels in Air; Propane, Dodecane, and Jet-A Fuel, Combustion and Flame, Vol. 125 (2001), pp.1320-1328.

(13) Beduneau, J. L., Kim, B., Zimmer, L., Ikeda, Y., Measurements of minimum ignition energy in premixed laminar methane/air flow by using laser induced spark, Combustion and Flame, Vol. 132 (2003), pp.653-665.

(14) Kopecek, H., Maier, H., Reider, G., Winter, F., Wintner, E., Laser ignition of methane-air mixtures at high pressures, Experimental Thermal and Fluid Science, Vol.27 (2003), pp.499-503.

(15) Beduneau, J. L., Ikeda, Y., Spatial characterization of laser-induced sparks in air, Journal of Quantitative Spectroscopy \& Radiative Transfer, Vol.84 (2004), pp.123-139.

(16) Bradley, D., Sheppard, C. G. W., Suardjaja, I. M., Woolley, R., Fundamentals of high-energy spark ignition with lasers, Combustion and Flame, Vol.138 (2004), pp.55-77.

(17) Phuoc, T. X., Laser-induced spark ignition fundamental and applications, Optics and Lasers in Engineering, Vol.44 (2006), pp. 351-397.

(18) Kawahara, N., Tomita, E., Nakayama, T., Ikeda, Y., Nishiyama, A., Spatial and Temporal Characteristics of Laser-induced Air Plasma, AIAA Paper, No, 2006-1461, (2006).

(19) Kawahara, N., Beduneau, J. L., Nakayama, T., Tomita, E., Ikeda, Y., Spatially, temporally, and spectrally resolved measurement of laser-induced plasma in air, Applied Physics B, Vol.86, (2007), pp.605-614.

(20) Hori, T., Akamatsu, F., Shibahara, M., Miyata, D., Katsuki, M., Laser-Induced Breakdown Analysis Using Nd: YAG Laser, Journal of High Temperature Society, Vol.31, No.1 (2005), pp.19-25.

(21) Lewis, B., von Elbe, G., Combustion, Flames and Explosions of Gases $3^{\text {rd }}$ edition, (1987), p.34, Academic Press.

(22) Nagasaki, S., Tanaka, Y., Kado, S., Tanaka, S., Efficiency of Time Resolved Laser Induced Breakdown spectroscopy for Particle Detection and Energy Transfer of Breakdown Plasma, Journal of Nuclear Science and Technology, Vol.1, No.4 (2002), pp.150-154.

(23) Yu, L. Laux, C. O., Packan, D. M., Kruger, C. H., Direct-current glow discharges in atmospheric pressure air plasmas, Journal of Applied Physics, Vol.91, No.5 (2002), pp.2678-2686.

(24) Foltin, V., Czechoslovakia Journal of Physics, Vol.56, No.8 (2006), pp.712-720.

(25) Dinescu, G., Aldea, E., Giordi, M. L. D., Luches, A., Perrone, A., Zocco, A., Optical emission spectroscopy of molecular species in plasma induced by laser ablation of carbon in nitrogen, Applied Surface Science, Vol.127-129 (1998), pp.697-702.

(26) Luque, J., Crosley, D. R., Database and Spectral Simulation for OH A-X, OD A-X, NO A-X, B-X, C-X, D-X, CH A-X, B-X, C-X, CN B-X, SiH A-X and CF A-X, SRI Report MP 99-009 (1999).

(27) Niioka, T., Kono. M., Sato, J., Fundamental of Combustion Phenomena(in Japanese), Ohmsha, (2001), p.83.

(28) Warnatz, J., Mass, U, Dibble, R.W., Combustion, 3rd Ed., (2001), p.89. 